\title{
Regulatory T-lymphocytes in asthma
}

\author{
A.J.M. van Oosterhout* and N. Bloksma\#
}

ABSTRACT: T-helper cell type (Th)2 lymphocytes play an important role in the initiation, progression and persistence of allergic diseases, including asthma. However, little is known about immunoregulatory mechanisms that determine susceptibility to, severity of, or persistence of asthma. The concept of a disturbed Th1/Th2 balance, although having furthered the present understanding of immunoregulation in asthma, has recently been named a "procrustean paradigm", because of its failure to adequately explain many (pre)clinical observations.

In recent years, the general knowledge regarding the regulation of infectious, autoimmune diseases, asthma and allergen immunotherapy by T-regulatory (Treg) cells, has rapidly increased. Many different Treg subsets have been described, including CD8+ Treg cells, natural killer (NK) cells and several different CD4+ Treg cell subsets.

In this review, the authors will focus on two major and well-described CD4+ Treg cell subsets. These consist of naturally occurring CD25+ Treg cells and adaptive Treg cells that are postulated to prevent immune responses against self-antigens and adaptive immune responses, respectively.

The adaptive T-regulatory cells are further subdivided into T-regulatory cells type 1 and Thelper cell type 3 that mediate suppression exclusively via the cytokines interleukin-10 and transforming growth factor- $\beta$, respectively.

KEYWORDS: Allergy, asthma, hygiene, immunotherapy, regulatory T-cell, T-helper cell type 2

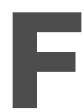
oreign antigens, including allergens or pathogens, that enter the body are taken up by so-called antigen-presenting cells (APC), which process the antigens and present peptides, thereof, in the context of major histocompatibility complex class (MHC) II molecules on their cell surface. A fraction of the CD4+ Tlymphocytes, also called T-helper (Th) lymphocytes, are activated by cognate interaction of the T-cell receptor (TCR) with the peptide-MHC II complex on APC when there are sufficient co-stimulatory signals, i.e. CD28:B7 [1]. Once activated, the Th-cells orchestrate adaptive antigen-specific cell-mediated and humoral immune responses. Incited by the role of CD4+ T-lymphocytes in the production of immunoglobulin (Ig) E antibody by B-lymphocytes, subsequent studies in the late 1980s demonstrated that they are also involved in the pathophysiology of allergic asthma [2,3].

The discovery of the mutual inhibitory effects of Th1 and Th2 cells in mice [4], prompted the postulate that an imbalance between these two arms of the immune response would underlie Th1-mediated autoimmune diseases as well as
Th2-mediated allergic diseases, including asthma $[5,6]$. However, the balance between Th1 and Th2 cells appeared insufficient to explain many experimental observations [7-9]. First, Th1 cells do not always appear beneficial in mouse models of allergic asthma, and were found to contribute to or to exacerbate, disease manifestations [1014]. This is in accordance with the observed appearance of Th1 cells or the cytokine interferon (IFN)- $\gamma$, not only in chronic atopic dermatitis and asthma, but also during allergic sensitisation [1518]. Secondly, Th2-skewed parasitic helminth infections did not appear to be associated with increased manifestations of allergy and asthma but, on the contrary, appeared to protect against these diseases [19]. Finally, epidemiological data from the 1960s onwards have shown a parallel rise in the prevalence of Th2-mediated allergic diseases, including asthma and Th1-mediated (auto-) immune diseases, such as type 1 diabetes, multiple sclerosis, and Crohn's disease [20, 21]. Whereas these data do not exclude a mutual inhibitory effect of Th1 and Th2 responses, a more powerful control mechanism is likely to be at play. At present, naturally occurring and adaptive T-regulatory cells (Treg) cells (nTreg
AFFILIATIONS

*Laboratory of Allergology and Pulmonary Diseases, Dept Pathology and Laboratory Medicine, University Medical Center Groningen,

Groningen University, Groningen, and \#Faculty of Biology, Utrecht University, Utrecht, The Netherlands.

\section{CORRESPONDENCE}

A.J.M. van Oosterhout Laboratory of Allergology and Pulmonary Diseases and Dept of Pathology and Laboratory Medicine UMCG

P.0. Box 30.001

$9700 \mathrm{RB}$, Groningen

The Netherlands

Fax: 31503121576

E-mail:

a.j.m.van.oosterhout@path.umcg.nl

Received:

February 012005

Accepted after revision:

June 102005

European Respiratory Journal

Print ISSN 0903-1936

Online ISSN 1399-3003 


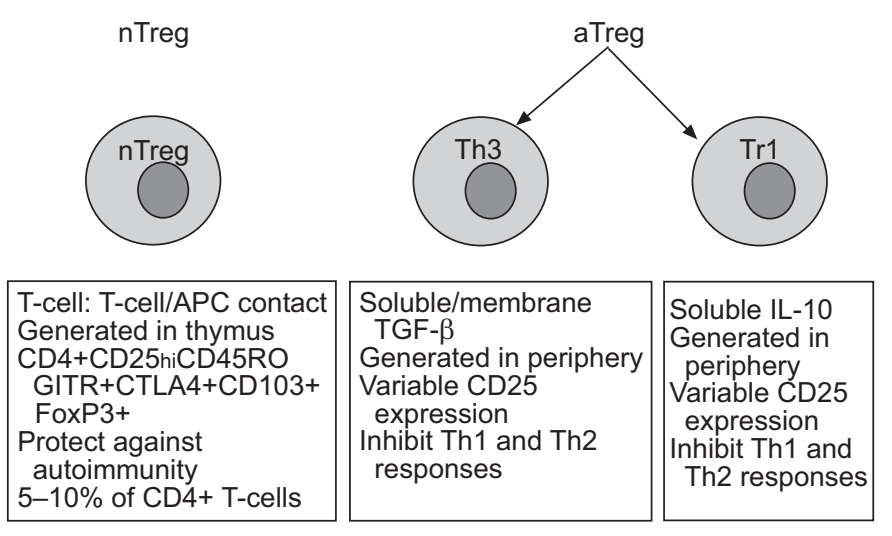

FIGURE 1. Major characteristics of subsets of CD4+ T-regulatory (Treg) cells based on cell-surface markers, immunosuppressive cytokine secretion and suppressive action. nTreg: natural Treg; aTreg: adaptive Treg; Th; T-helper cell; Tr1: T-regulatory cell type 1; APC: antigen-presenting cells; TGF: transforming growth factor; IL: interleukin.

and aTreg, respectively) are taking the centre stage as the crucial immunoregulatory cells that are capable of suppressing Th1- and Th2-mediated adaptive immune responses in a cell contact-dependant fashion directly or by acting on APCs. They also appear to offer exciting new views of the initiation and progression of asthma and other allergic diseases. In figure 1, the major characteristics of CD4+ Treg cells are depicted.

\section{NATURAL T-REGULATORY CELLS}

CD4+CD25+ nTreg cells are generated in the thymus and reside in the blood and other peripheral lymphoid tissues at a frequency of $5-10 \%$ of all CD4+ cells and in the bone-marrow $\geqslant 20 \%$, both in mice and in humans [22-25]. Passive transfer of nTreg cells has been shown to suppress autoimmune diabetes, inflammatory bowel disease and transplant rejection in rodents. nTreg cells express a normal $\alpha / \beta$ TCR repertoire and can be activated by anti-CD3 [24, 26, 27]. It has been shown that nTreg cells have a high TCR affinity for self-peptides that might be encountered in the periphery, which may explain the constitutive expression of the activation marker, CD25 [27-29]. However, the target autoantigens recognised by nTreg cells are, at present, unknown. Although still controversial, accumulating data reports that nTreg cells can also be generated in the periphery from conventional CD4+ T-cells upon exposure to pathogen-derived antigens [30], low-dose antigenic peptide via prolonged subcutaneous infusion [31], the cytokine transforming growth factor (TGF)- $\beta$ [32-34], or glucocorticoids [35] (fig. 2).

Studies performed so far with human CD4+CD25+ nTreg cells, without exception, confirmed data obtained in mouse studies $[2,23,27,36]$. Human CD4+CD25+ nTreg cells show poor proliferative responses upon stimulation with anti-CD3, even in the presence of interleukin (IL)-2, suppress proliferative responses of conventional CD4+CD25- T-cells, and produce low levels of the immunosuppressive cytokines, IL-10 and TGF- $\beta$, while the suppression, at least in vitro, cannot be overcome by the addition of neutralising antibodies to these cytokines or their respective cell-surface receptors. However, a role for IL-10 or (membrane-associated) TGF- $\beta$ in vivo, cannot be completely excluded, as indicated by mouse experiments. Their involvement may be indirect, since nTreg cells were found to aid the generation of aTreg cells that mediate suppression by these cytokines (fig. 2) [39, 40].

In vitro, nTreg cells appear to suppress adaptive $\mathrm{T}$-cell responses exclusively by T-cell:T-cell/APC contact. The molecular basis for this suppression is unknown at present. The cell-surface molecules, CTLA-4 [41, 42], Notch-3 [43], and LAG-3 [44], as well as the intracellular enzyme, haeme oxygenase-1 (HO-1) that generates the immunosuppressant, carbon monoxide [45], have all been shown to play a role. Interestingly, CTLA-4 ligation of B7-1 or B7-2 on dendritic cells (DCs) was found to result in the induction of the enzyme indoleamine 2,3-dioxygenase (IDO) in DCs [46, 47]. IDO is the rate-limiting enzyme in the conversion of tryptophan to kynurenin and other down-stream metabolites. It may also mediate potent immunosuppression by T-cell starvation, due to the depletion of tryptophan or antiproliferative and proapoptotic effects of its down-stream metabolites [48, 49]. In contrast to CTLA-4 ligation of DC-expressed B7 molecules, their ligation by CD28 stimulates T-cells and interestingly, induces IL-6 production that prevents upregulation of IDO $[50,51]$. In summary, nTreg cells may suppress effector T-cells by different pathways, as schematically depicted in figure 2 .

A major issue in the study of Treg subsets is the lack of discriminative cell-surface markers (fig. 1). CD25 expression has been linked to the subpopulation of nTreg cells. However, CD25 is a general activation marker of T-cells and CD4+CD25+ cells may, therefore, contain recently activated conventional Tcells. Thus, in a "resting" situation when there is no ongoing immune response, CD25 may be an appropriate marker for nTreg cells, but during active disease it is not sufficiently distinctive for this purpose. However, as nTreg cells appear to express very high levels of CD25, this could be useful to differentiate between activated T-cells and nTreg cells [52]. nTreg cells are further characterised by a set of cell-surface markers, none of which are able to completely discriminate between nTreg cells and activated conventional T-cells. These markers include CTLA-4, CD45RBlow/CD45RO (mouse/ human), CD38, CD62L, glucocorticoid-induced tumour necrosis factor (TNF) receptor (GITR, also known as TNFRSF18) and neuropilin-1, of which the latter is the only one that is downregulated on activated conventional T-cells (fig. 1) [24, 53]. Furthermore, subpopulations of nTreg cells have been described based on the expression of integrins. Among these, $\alpha \mathrm{E} \beta 7$ (CD103) appeared to define a subpopulation of $n$ Treg cells that is highly potent in suppression. This population is considered to be restricted to mucosal surfaces, since it binds via $\alpha \mathrm{E} \beta 7$ to E-cadherin expressed by mucosal epithelial cells [54]. Interestingly, these $\alpha E \beta 7+n T r e g$ cells express high levels of adhesion molecules and chemokine receptors that suggest a role at inflammatory sites [55]. In addition, STASSEN et al [37] have described $\alpha 4 \beta 7+$ and $\alpha 4 \beta 1+$ nTreg cells populations that induce T-regulatory cells type 1 (Tr1) cells or Th3, respectively. It can be concluded that nTreg cells can exert powerful immunosuppressive effects and current knowledge is rapidly progressing, although many details still need to be unravelled and observations reproduced before the bigger picture will emerge. 


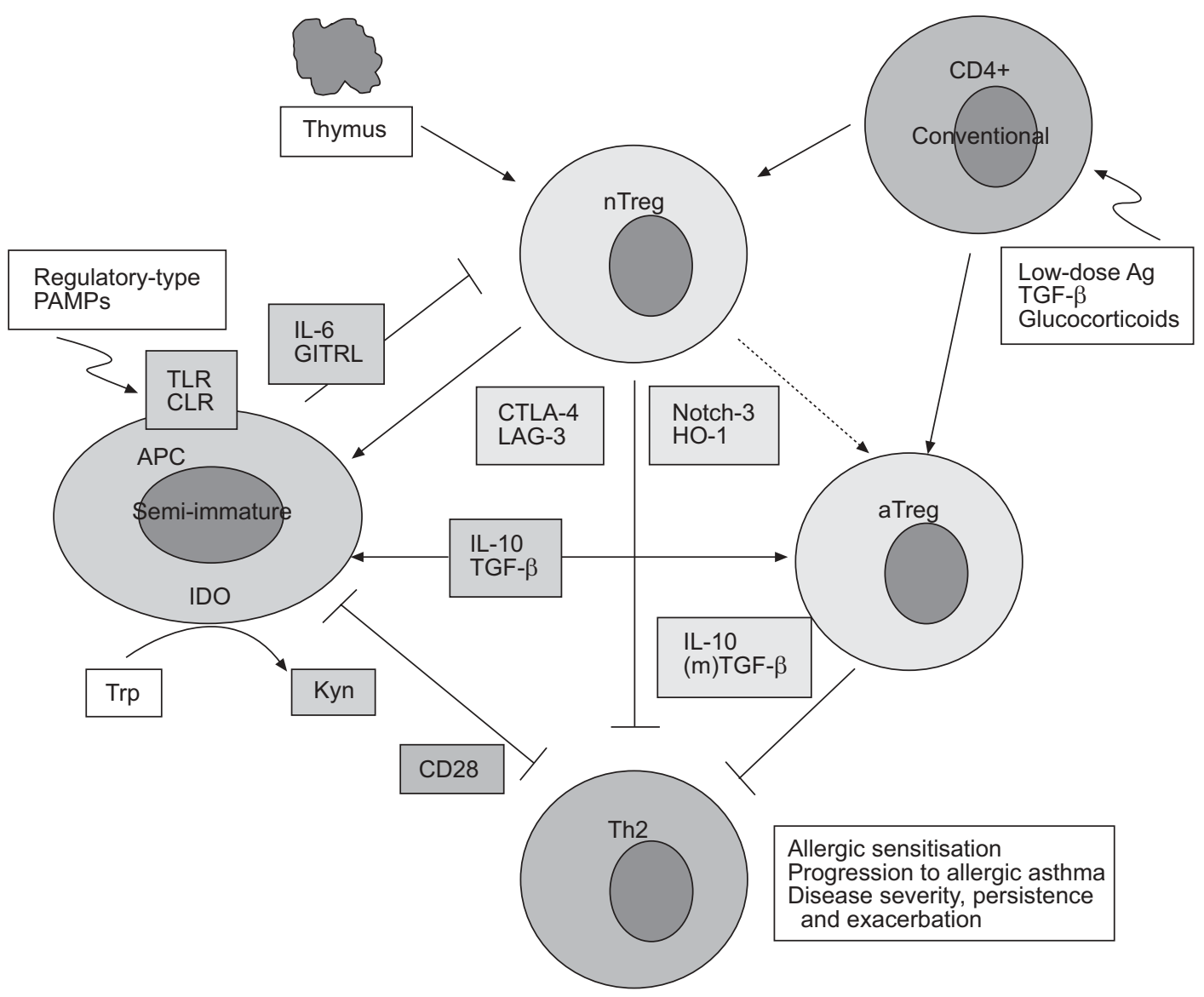

FIGURE 2. Schematic representation of the suppressive mechanisms of T-regulatory (Treg) cells subsets and their interactions with each other and antigen-presenting cells (APCs), in particular on dendritic cells. Natural Treg cells (nTreg) are predominantly generated in the thymus, but can also develop from conventional CD4+ cells by specific conditions or signals. nTreg cells suppression of effector T-helper cell type 2 (Th2) cell responses involves the cell surface molecules CTLA-4, Notch-3, and LAG-3, and the intracellular enzyme, haeme oxygenase (HO)-1. CTLA-4 and CD28 deliver opposite signals to APCs, thereby regulating indoleamine 2,3-dioxygenase (IDO) activity and its anti-proliferative effects on effector T-cells. The suppressive effects of nTreg cells are abrogated by GITRL and interleukin (IL)-6 that can be expressed by APCs. Immature or semi-mature APCs producing IL-10 or transforming growth factor (TGF)- $\beta$ generate T-regulatory cell type 1 (Tr1)- and Th3-type aTreg cells, respectively. Production of these cytokines by APCs can be induced by so-called regulatory-type pathogen-associated molecular patterns (PAMPs). Data suggest that nTreg cells also mediate the development of aTreg (Tr1, Th3) cells. IL-10 and (membrane-associated) TGF- $\beta$ derived from aTreg cells and potentially nTreg cells suppress effector Th2 cell responses directly or by acting on APCs. Trp: tryptophan; Kyn: kynurenin; TLR: Toll-like receptor; CLR: C-type lectin receptor; Ag: antigen. See text for further details regarding these interactions.

\section{FOXP3 AND NATURAL T-REGULATORY CELLS}

Expression of specific transcription factors have been shown to be crucial to the differentiation of Th cell subsets from naïve, unpolarised T-cells. Notably, T-bet and GATA-3 are crucial to Th1 and Th2 cytokine expression, respectively [56]. Recently, the transcription factor, Foxp3, was shown to be selectively expressed by nTreg cells both in mice and humans [57-60]. The Foxp3 mRNA level in resting nTreg cells is 100-fold higher than in resting and activated conventional $\mathrm{CD} 4^{+} \mathrm{T}$-cells. Therefore, Foxp3 represents a more specific marker for nTreg cells than cell-surface molecules currently used, such as CD25, CTLA-4, and GITR. However, a major disadvantage for nTreg characterisation is that Foxp3 expression is currently determined by quantitative PCR and not by flow cytometry.

Interestingly, ectopic expression of Foxp3 by naïve T-cells appeared essential to the generation of Treg cells as demonstrated by cell-surface markers and cell-cell contact dependent, but IL-10- and TGF- $\beta$-independent, antiproliferative effects on T-cells [58]. Vice versa, Foxp3 knockout or mutant ("scurfy") mice lacked CD4+CD25+ nTreg cells and developed a lethal autoimmune syndrome $[59,60]$. Moreover, TGF- $\beta$ can induce Foxp3 expression in naïve T-cells leading to nTreg cell generation in mice $[32,33]$. Data demonstrates that Foxp3 is a master regulatory gene for the development and function of nTreg cells and confirms its role in the suppression of autoimmune diseases. The crucial role of the human homologue FOXP3 in nTreg cells has now also been firmly demonstrated in humans by YAGI et al. [61]. They demonstrated that the FOXP3 gene and its protein product were preferentially expressed in peripheral CD4+CD25+ nTreg cells of normal individuals. Furthermore, naïve conventional CD4+CD25- $\mathrm{T}$ cells could be converted into nTreg cells by ex vivo retroviral gene transfer of FOXP3, as confirmed by cell-surface markers and cell-cell contact-dependent antiproliferative effects on conventional T-cells. The fact that 
FOXP3 is essential to nTreg cell function may open novel therapeutic strategies aimed at the induction of FOXP3 to convert conventional CD4+ T-cells into nTreg cells with the ultimate goal to reverse aberrant Th2-mediated allergic asthmatic responses.

\section{ADAPTIVE T-REGULATORY CELLS}

The aTreg cells are generated in the periphery from naïve Tcells after encountering antigens presented by tolerogenic DCs, which are functionally distinct from immunogenic DCs that promote Th1 or Th2 cell generation [62]. As already indicated, aTreg cells are subdivided into Tr1 and Th3 that mediate suppression via the cytokines, IL-10 and TGF- $\beta$, respectively (fig. 1). The suppressive action of these cytokines is predominantly directed at inhibiting the expression of MHC II and costimulatory molecules by APCs. In addition, direct effects at the T-cell level have been described. TGF- $\beta$ inhibits proliferation and cytokine secretion by resting, but not activated, T-cells [63] and IL-10 may sensitise activated T-cells to the suppressive action of TGF- $\beta$ by enhancing TGF- $\beta$ receptor type II expression on these cells [63]. TGF- $\beta$ has been shown to induce the expression of immunosuppressive IL-10 by T-cells [64]. Thus, IL-10 and TGF- $\beta$ may have synergistic, suppressive effects on T-cell proliferation and immunostimulatory cytokine secretion.

The aTreg subsets variably express CD25, depending on their level of activation and cannot be distinguished solely by the expression of IL-10 or TGF- $\beta$, because it is not an exclusive property of these subsets. In contrast to Th1 and Th2 cells, Tr1 cells can also be characterised by absent or low IL-2 and IL-4 production, although they may express IL-5, IFN- $\gamma$ and TGF- $\beta$. Th3 cells may, in addition to TGF- $\beta$, also express variable amounts of IL-4 and IL-10. Hence, demonstration of the involvement of Tr1 or Th3 cells in adaptive immune responses requires determination of a discriminative cytokine profile.

\section{ROLE OF DENDRITIC CELLS IN GENERATING ADAPTIVE T-REGULATORY CELLS}

DCs play a crucial role in the generation of all adaptive T-cell subsets, including aTreg cells, which has been reviewed in detail elsewhere $[65,66]$. In short, immature DCs in peripheral tissues acquire pathogens and or antigens from their vicinity through phagocytosis, endocytosis and pinocytosis, and mature upon recognition of so-called "danger signals". These signals are derived either directly from encountered pathogens/antigens or from endogenous mediators that are present or generated in the local microenvironment [62, 65]. Microbial pathogens contain ligands (pathogen-associated molecular patterns: PAMPs) that are recognised through so-called "pattern recognition receptors" (PRRs) of which the family of Toll-like receptors (TLRs) and C-type lectin receptors (CLRs) are prime examples [67-70]. Bacteria harbour an abundance of PAMPs ranging from cell wall components (lipopolysaccharides, lipoproteins, peptidoglycans, lipoarabinomannans) to DNA containing unmethylated CpG motifs [69]. Recognition of the PAMPs by TLRs causes signalling through a conserved pathway leading to the activation of nuclear factor (NF)- $\kappa \mathrm{B}$, a family of transcription factors implicated in many inflammatory responses and crucial to the maturation of DCs $[69,71]$. The maturation of DCs is characterised by high levels of expression of MHC-II and costimulatory molecules such as, B7-1, B7-2, and CD40 and by pro-inflammatory cytokine secretion. TLRs are not only involved in DC maturation, but also in the abrogation of Treg cell-mediated suppression. Thus, the combined action may enable development of full-blown immune responses [72]. However, TLRs are also instrumental to the induction of tolerogenic DCs, indicating that the codes instructing development of immunogenic or tolerogenic DCs are very complex.

Tolerogenic DCs generally are semi-mature cells with increased expression of MHC II and B7-2, but low levels of expression of CD40 and absent production of the proinflammatory cytokines, IL-6 and TNF- $\alpha$ [73]. Repetitive stimulation of T-cells with immature, antigen-presenting DC has been shown to generate IL-10 producing Tr1 cells [74-76]. Likewise, inhibition of DC maturation by inhibiting NF- $\kappa$ B activation with the biologically active form of vitamin D3 $\left(1,25(\mathrm{OH})_{2}\right.$ VitD3) or glucocorticoids, induces Tr1-like cells in vitro and tolerance in mouse models of transplantation and autoimmune diseases in vivo [77-79]. However, Tr1-like cells can also be induced in vitro in the absence of DCs by activating naïve CD4+ T-cells in the presence of immunosuppressive drugs e.g. 1,25(OH) $)_{2}$ VitD3 or glucocorticoids [80].

The mechanisms by which so-called tolerogenic DCs induce the development of aTreg cells is not completely understood. The induction of Tr1 or Th3 cells is related to the production of IL-10 or TGF- $\beta$ by (semi/immature) DCs, respectively $[65,73]$. Many pathogens, including viruses, parasites, fungi and bacteria, and isolated, so-called regulatory-type PAMPs have been shown to induce the production of either one or both of these cytokines by DCs, and to facilitate induction of aTreg cells in this way (fig. 2) [30, 65, 70]. The local microenvironment also appears to influence the development of tolerogenic DCs, and the subsequent generation of aTreg cells as shown by two forms of tolerance induced via the mucosal route [81]. Tolerance by intranasal application of ovalbumin has been associated with the appearance of DCs in the lung that could generate Tr1 cells ex vivo. It appeared to be mediated by DCderived IL-10 and ICOSL: ICOS interaction $[82,83]$. Tolerance by intragastric ovalbumin administration, so-called "oral tolerance", has been associated with TGF- $\beta$-producing DCs that generate Th3 cells [81]. A role for commensal bacteria, present at mucosal surfaces in particular the gut, in the induction of these allergen-specific aTreg responses cannot be excluded [84-86]. One of the molecular mechanisms may be the inhibition of NF- $\kappa B$ activation in epithelial cells by commensal bacteria, leading to an anti-inflammatory and tolerogenic microenvironment $[87,88]$. Whether similar processes occur at the airway mucosa is unknown at present. The instruction of DCs by microbial ligands leading to immunogenic or tolerogenic responses may be an important link to the hygiene hypothesis of allergic diseases, including asthma. Moreover, this knowledge may be of use in the development of novel therapeutics that target DCs [89].

\section{T-REGULATORY CELLS AND ASTHMA}

Theoretically Treg cells may interfere with the development of allergic diseases and asthma at different stages, such as allergic sensitisation, progression to allergic inflammation, airway remodelling and airway hyperresponsiveness (AHR), and 
persistence of disease manifestations. However, at present little is known about the role of Treg cells in allergy and allergic asthma.

Sensitisation to environmental allergens is known to occur typically in early childhood or even before birth, but subsequent progression to persistent atopic asthma, which may not manifest itself for several years, is restricted to only a subset of atopics [90]. This has led to the hypothesis that the induction of a down-regulatory Th1 response, supposedly by microbial stimulation, during the first years of life, prevents allergic sensitisation and progression to atopic asthma [91-93]. Irrespective of this hypothesis, Treg cells may also be instrumental in preventing allergic sensitisation and progression to asthma. The nTreg cells are present in cord blood and probably play an immunoregulatory role in intrauterine life [94]. Recently, THORNTON et al. [95] described how cultures of cord blood T-cells, in the presence of allergens, led to a relative increase in the number of CD4+CD25+ Treg cells. The increase did not appear to be due to proliferation of these nTreg cells, but rather to apoptosis of the proliferating conventional T-cells. Interestingly, these nTreg cells acquired suppressive properties during culture with an allergen. The significance of the in vitro observation for understanding allergic sensitisation and progression to asthma is unclear. More research into the mechanisms by which nTreg cells promote the development of tolerance to harmless environmental allergens during intrauterine and neonatal life is needed. It may lead to novel strategies for primary prevention of allergic diseases, including asthma.

Two recent studies have examined the role of CD4+CD25+ Tcells in adult allergic individuals. BELLINGHAUSEN et al. [96] found similar activities of peripheral blood nTreg cells from grass or birch pollen allergic rhinitis patients and healthy controls. They proliferated poorly, produced low levels of cytokine and inhibited proliferation and production of Th1 and Th2 cytokines, but not IL-10, by conventional CD4+CD25- Tcells. Moreover, the inhibition was not reversible by antibodies to IL-10, TGF- $\beta$ or CTLA-4, but could be reversed by IL- 2 , which is in agreement with nTreg cell function. Since no differences were observed between healthy and atopic donors, they concluded that nTreg cells are present and functional in most atopic patients. In contrast herewith, LING et al. [97] showed that nTreg cells from atopic donors suppressed proliferation and IL5 production of autologous CD4+CD25- T-cells significantly less than nTreg cells from healthy donors, in particular during the pollen season. The latter study also verified the true nTreg cell nature of the isolated CD4+CD25+ cells by measurement of FOXP3 mRNA levels. Since both studies used allergen in the presence of APCs for T-cell stimulation, allergen-specificity of the nTreg cells was demonstrated, so confirming that nTreg cells can be generated in the periphery upon exposure to foreign antigens or pathogens. A likely explanation for the contradictory findings is the time point at which the blood samples were taken. In the study of BELLINGHAUSEN et al. [96] this may have been out of the pollen season, when, as shown by LiNG et al. [97], nTreg cell activity of allergic patients was substantially lower than during the pollen season. Furthermore, BELLINGHAUSEN et al. [96] did not analyse whether the CD4+ CD25+ T-cells expressed higher levels of FOXP3 mRNA compared with conventional CD4+CD25- T-cells, thereby not verifying the purity of the T-cell populations used. Although further studies are needed, observations suggest that there may be an inverse correlation between nTreg cell activity and clinical manifestations of allergic disease, as previously observed for autoimmune diseases [98]. If so, it needs to be determined whether clinical disease manifestations are the cause or the consequence of decreased nTreg activity.

An interesting observation regarding the role of nTreg cells in the manifestation of allergy comes from KARLSSON et al. [99] in children with cow's milk allergy. Children who outgrew their allergy had higher numbers of CD4+CD25+ cells in their blood than those who maintained clinically active allergy. The increased numbers coincided with decreased in vitro $\mathrm{T}$-cell proliferative responses to the food-allergen, bovine $\beta$-lacto globulin, but not with proliferative responses to polyclonal stimulation, again indicating the presence of allergen-specific nTreg cells. These had marked suppressive activity, since depletion of CD25+ cells led to a striking (five-fold) increase in the $\mathrm{T}$-cell proliferative response to the food allergen. The suppression by the CD4+CD25+ T-cells was partially dependent on cell contact and not due to increased IL-10 or TGF- $\beta$ production, supporting the conclusion that these cells were indeed nTreg cells. However, involvement of the immunosuppressive cytokines cannot be completely excluded since no blocking studies were carried out. Studies so far indicate the potential role of nTreg cells in the spontaneous reversal of asthma and other allergic diseases and further studies may shed new light on this intriguing phenomenon.

While aTreg cells are clearly implicated in allergen immunotherapy (referred to later), their putative role in the prevention and severity of allergic asthma is largely unknown at present. The role of IL-10 producing T-cells in the severity of allergic asthma in adults has been studied by MAтSUмOTO et al. [100] by comparing mild, severe-stable and severe-unstable asthmatics. The frequency of IL-10 producing CD4+ T-cells as determined by flow cytometry after anti-CD3/anti-CD28 stimulation was lower in the severe unstable group as compared with the mild or the severe-stable group and could not be attributed to the use of inhaled glucocorticoids. Although these data need confirmation, there is an indication that the number of IL-10 producing cells, potentially $\operatorname{Tr} 1$ cells, may be related to the prevention of asthma exacerbations. AKDIS et al. [101] analysed the frequency of allergen-activated T-cells according to their cytokine secretion profile in healthy and pollen or house-dust mite (HDM) allergic individuals. They observed a delicate balance in the frequency of Tr1 cells and Th 2 cells. The Tr1 cells represented the dominant subset in healthy individuals, whereas high frequencies of IL-4 secreting T-cells were present in allergic individuals. Interestingly, blocking of the $\operatorname{Tr} 1$ activity enhanced allergen-induced Th2 cell activation in vitro. Furthermore, they demonstrated that the suppressive action of the Tr1 cells in vitro was mediated by the joint action of IL-10, TGF- $\beta$, CTLA- 4 and PD- 1 . Data suggest that Tr1 cells represent a Treg cell subset involved in preventing the development of allergic diseases.

Despite the limited number of studies, it can be concluded that nTreg and aTreg cells are important in the prevention of allergic sensitisation as well as progression to established allergic diseases, including asthma. In established disease, they 
function to reduce severity and to prevent exacerbations. Although these studies need to be expanded and confirmed by others, Treg cells may offer new possibilities for the monitoring of diseases and the development of novel therapeutic strategies.

\section{GLUCOCORTICOIDS AND T-REGULATORY CELLS}

Glucocorticoids are widely used in the treatment of allergic asthma for their potent anti-inflammatory effect. It has recently been shown that pre-incubation of CD4+CD25+ nTreg cells with glucocorticoids, potentiated their antiproliferative effects on allergen-stimulated CD4+CD25- T-cells from atopic as well as nonatopic donors [102]. Interestingly, the glucocorticoidinduced potentiation of suppressive activity was paralleled by enhanced IL-10 production and anti-IL-10 could reverse the glucocorticoid-dependent, but not the baseline, suppression. Thus, nTreg cell-derived IL-10 mediates the glucocorticoidinduced suppression. If operative in vivo, it may represent an additional mechanism by which glucocorticoids inhibit inflammation. Glucocorticoids can also influence Tr1/nTreg cell development in vivo, as shown by KARAGIANNIDIS et al. [35]. They demonstrated how inhalation or systemic glucocorticoid treatment of asthma patients increased the levels of FOXP3 as well as IL-10 mRNA in peripheral blood CD4+ T-cells. Moreover, glucocorticoids increased these mRNA levels in short-term cultured CD4+ T-cells. Altogether, the data demonstrates that glucocorticoid treatment potentiates the immunosuppressive effects of nTreg and/or Tr1 cells, probably by increasing IL-10 production. The Treg population generated by glucocorticoid treatment displayed characteristics both of nTreg cells (FOXP3) and Tr1 cells (IL-10), but whether it is a pure population of CD4+CD25+ nTreg cells or a mixture of nTreg cells and Tr1 cells cannot be concluded from these studies. Likewise, it is unknown whether the induction of $\operatorname{Tr} 1$ cells is dependent on the presence of nTreg cells. In literature, there is still controversy as to whether Tr1 cells can express FOXP3 [24, 61]. Furthermore, in contrast to the mouse, activation of human naïve CD25- T-cells can result in FOXP3 expression and associated suppressor activities [24, 57, 103]. The data described above supports the concept that nTreg cells, with high FOXP3 expression and suppressive activity, can develop from conventional peripheral T-cells under specific in vivo activation conditions [24]. It is an intriguing concept, since it opens up the possibility for novel therapeutic strategies aiming at stable induction of nTreg/Tr1 cells. However, this may be a more complex goal than the data suggests since glucocorticoid treatment in asthma does not lead to long-term suppression.

\section{NATURAL T-REGULATORY CELLS AND MOUSE MODELS OF ALLERGIC ASTHMA}

Mouse models of allergic asthma have been very helpful in the understanding of the immunological mechanisms of $\operatorname{IgE}$ regulation, Th1/Th2 balance, eosinophilic airway inflammation and development of AHR. Furthermore, many experimental therapeutic approaches have first been examined in mouse models. The mouse has also been widely used with regards to the role of Treg cell subsets in immunoregulation, in particular in models of autoimmune and infectious diseases. However, mouse studies on the role of Treg cells in different aspects of allergic disease and asthma are less abundant and often contradictory. In different, sometimes rather artificial, models both stimulatory and inhibitory effects of nTreg cells have been observed on IgE production, Th2 responses and airway eosinophilia, whereas no effect on AHR has been observed [104-107]. In the studies cited above the nTreg cells were characterised by the expression of CD25 only and in most models endogenous antigen expression or a T-cell receptor transgenic system was used. Therefore, it cannot be excluded that some of these observations are confounded by the involvement of aTreg cells, Tr1 cells in particular [107]. Recently, VAN OOSTERHOUT et al. [108] demonstrated in a BALB/c mouse model of asthma that nTreg (CD4+ CD25+CD45RBlowGITR+) cells are present in the lung tissue of sensitised mice and increase upon allergen inhalation. Inhibition of nTreg cell suppression by ligation of GITR [109, 110] potentiated respiratory allergen-induced AHR and $\operatorname{IgE}$ production, and Th2 cytokine levels in lung lavage fluid, but not airway eosinophilia [108]. Increased levels of Th2 cytokines were also found in recall cultures of lung T-cells in the presence of nTreg cell-inhibiting anti-GITR. Data was suggestive of the suppressive potential of nTreg cells. However, since GITR was recently demonstrated on activated conventional CD4+ T-cells and can function as a costimulatory molecule [111-114], it cannot be excluded that the potentiation of asthma manifestations by GITR ligation is due to potentiation of Th2cell effector function. Interestingly, the natural ligand of GITR (GITRL) is expressed by resting DCs, macrophages and B-cells, which strongly suggests that APCs modulate the immunosuppressive function of nTreg cells [110, 115-117]. Considering these findings, local stimulation of nTreg cell number or function in the airways may be a promising therapeutic approach that deserves further exploration.

\section{ADAPTIVE T-REGULATORY CELLS AND MUCOSAL TOLERANCE}

In the mouse, primary exposure to the model antigen, ovalbumin, via the respiratory mucosa either by inhalation or intranasal administration, has been shown to induce tolerance to the generation of an $\mathrm{IgE}$, but not Th1-associated $\mathrm{IgG}_{2} \mathrm{a}$, response and to subsequent antigen-induced airway manifestations of asthma [118-121]. This form of tolerance appeared to be mediated by the induction of Treg cells, but controversy exists regarding the subset(s) involved [122]. Active induction of Tr1-like cells by IL-10 producing DCs [82, 83] and of Th3/ nTreg like cells by a TGF- $\beta$-dependent mechanism [123] has been observed after primary ovalbumin exposure. An explanation for these different observations may be the dose of ovalbumin used. Whereas AKBARI et al. [82] treated mice intranasally with a relatively high dose, OsTROUKHOVA et al. [123] exposed mice to a low dose of aerosolised ovalbumin. In contrast to ovalbumin, intranasal treatment with a low dose HDM extract has been shown to induce allergic sensitisation and subsequent development of allergic airway inflammation and AHR [124]. Interestingly, CATES et al. [125, 126] showed that allergic sensitisation and subsequent inflammation in response to intranasal administration of HDM were mediated by granulocyte macrophage-colony stimulating factor (GMCSF). Vice versa, it has been shown that induction of GM-CSF production in epithelial cells by adenoviral GM-CSF gene transfection induces allergic sensitisation and allergic inflammation upon primary intranasal ovalbumin exposure [127]. The different capacities of allergens, such as HDM and pollen, 
and the innocuous antigen, ovalbumin, to cause allergic sensitisation may be related to proteolytic capacities of the allergens. These trigger GM-CSF production by airway epithelial cells, thus causing DCs maturation [128-131]. As mentioned earlier, immature DCs, in particular when they produce IL-10 or TGF- $\beta$, are potent inducers of aTreg cells. Moreover, suppression by nTreg cells is critically dependent on immature DCs and is readily reversed by maturation of these cells in response to GM-CSF [132]. Another epitheliumderived factor that may be involved in this process is thymic stromal lymphopoietin (TSLP) which can activate DCs to produce Th2-attracting chemokines and to induce naïve $\mathrm{CD} 4^{+}$ and $\mathrm{CD} 8{ }^{+} \mathrm{T}$ cell differentiation into effector cells with a typical pro-allergic phenotype [133-135]. However, it is unclear at present whether airway epithelium releases TSLP upon contact with proteolytic allergens. A major question regarding allergic sensitisation versus tolerance induction in humans is why airborne allergens induce allergic sensitisation in atopic, but not in nonatopic, individuals [132]. In addition to the proteolytic capacities of many airborne allergens, other factors such as the genetic background are involved. More knowledge about these factors may reveal new opportunities for prophylactic treatment of children with higher risks of developing allergic diseases.

\section{T-REGULATORY CELLS AND THE HYGIENE HYPOTHESIS}

The postulate of the hygiene hypothesis that there would be an inverse relation between the extent of exposure to microbial agents during early childhood and the prevalence of Th2mediated allergic diseases, has been supported by substantial evidence. However, the supposed underlying mechanism, that Th1 reactions as induced by microbial agents would suppress development of allergen-induced Th2 reactions, appear untenable. Notably, helminth infections that elicit strong Th2 reactions with high levels of $\mathrm{IgE}$ appeared protective against IgE-mediated allergies [19]. Moreover, the prevalence of Th1mediated autoimmune diseases has risen in parallel with Th2mediated allergies [21], although a decrease would have been expected, if Th1 and Th2 reactions would have effective mutually inhibitory activity. The new concept, therefore, assumes that the rise in allergic and autoimmune diseases is the result of a decrease in immunoregulatory control of Th1 as well as Th2 reactions, probably due to decreased exposure to microbial agents [8, 19, 136]. How microbial agents would restrain development of untoward immune responses is not fully understood at present, but there is increasing awareness that stimulation of Treg cell numbers or function, by microbial agents, may be involved. One of the mechanisms by which microbial agents would facilitate Treg cell induction has already been referred to in this review. Several regulatorytype PAMPs stimulate development of tolerogenic DCs by inducing IL-10 and/or TGF- $\beta$ production in these cells. However, since other PAMPs may promote development of mature, immunogenic DCs [65, 137], current understanding of the net result of DC exposure to intact microorganisms is presently insufficient. Nevertheless, pathogen-specific $\operatorname{Tr} 1$ cells were found in humans or mice upon infection with viruses (hepatitis C, Epstein-Barr), bacteria (Bordetella pertussis, Helicobacter hepaticus, Mycobacterium tuberculosis) or the parasite, Onchocerca volvulus as reviewed by MiLls [30].
Likewise, nTreg cells of undetermined specificity were found in HIV-infected humans and mice infected with viruses (Herpes simplex), bacteria (H. hepaticus, H. pylori), parasites (Schistosoma mansoni, Leishmania major, Plasmodium spp., Litomosoides sigmodontis), or fungi (Pneumocystis carinii, Candida albicans) [30, 138]. In many of the mouse infection models, in vivo depletion or transfer studies have shown that the pathogen-induced Treg cells inhibit specific $T$ cell responses and inflammatory immunopathology and prevent complete pathogen elimination from the host [30]. The Treg cell-dependent pathogen survival is not necessarily harmful to the host, because, as demonstrated for L. major, it leads to persistent immunity against re-infection, while complete eradication leads to loss of immunity [139]. Thus, the Treg cell-induced persistence of low numbers of pathogens in the body would result in persistently elevated levels of Treg cell activity. This, in turn may help to prevent the development of untoward allergic and autoimmune reactions by the so-called bystander suppression, since the suppressor effector function of nTreg cells and suppression by IL-10 derived from Tr1 cells are antigen nonspecific [26, 140,141]. In other words, Treg cellinducing pathogens may elevate the level of $\mathrm{T}$ cell regulation and so prevent sensitisation to environmental allergens, as schematically depicted in figure 3 . In addition to various pathogens, the intestinal flora may be a persistent cause of increased Treg cell surveillance in the body. This is clearly indicated by the observation that murine CD4+ T cells isolated from enteral lamina propria, mesenteric lymph nodes, or peripheral blood did not react to an extract of the sonicated lumenal content of colon and cecum, while vigorous proliferation was seen upon depletion of the CD4+CD25+ T cells [142].

Whether all or only certain species of the intestinal bacterial flora contribute to Treg cell surveillance in the body is not known at present. However, regarding the protective activity of probiotic lactic acid bacteria against development of allergic diseases $[143,144]$ and observations that children with higher counts of lactic acid bacteria in their faeces had a lower prevalence of allergic disease [145], it is tempting to speculate that the level of Treg cell activation by intestinal flora is influenced by its composition. Besides commensal intestinal bacteria, exposure to the orofaecal or foodborne pathogens, hepatitis A virus, H. pylori, and Toxoplasma gondii, as evidenced by seropositivity, appeared to be associated with a lower prevalence of atopy in Italian male cadets, especially in the case of seropositivity for at least two of the pathogens [146]. In the cumulative seropositives, allergic asthma appeared rare and allergic rhinitis infrequent. Since no associations were found between (cumulative) seropositivity for pathogens transmitted by other routes and the prevalence of atopy, it was concluded that inadequate stimulation of the gutassociated lymphoid tissue would enhance the risk of atopy. This conclusion could not be substantiated by a study of Danish subjects aged 15-69 yrs. Whereas it confirmed a lower prevalence of atopy in subjects with seropositivity for at least two of the above-mentioned orofaecal or foodborne pathogens, it did not find an association between atopy and cumulative seropositivity for the intestinal pathogens, Clostridium difficile, Campylobacter jejuni and Yersinia enterocolitica [147]. Thus, although it is still not clear whether stimulation of gut-associated lymphoid tissue is essential for providing 
a)

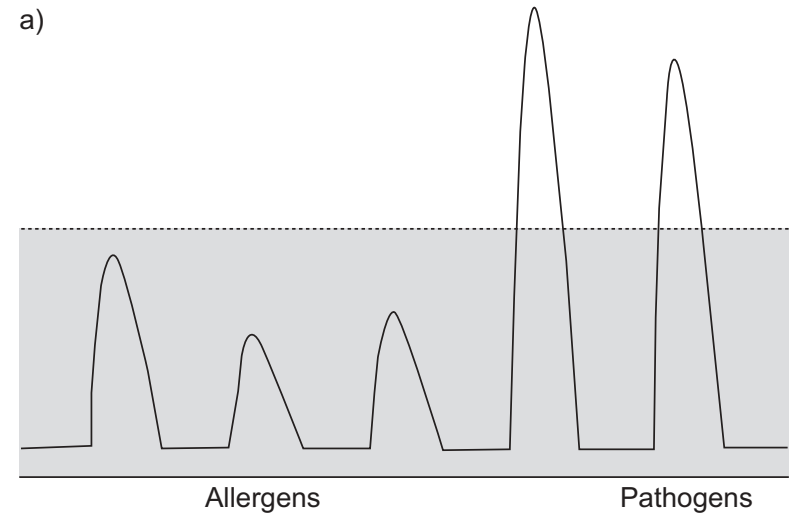

b)

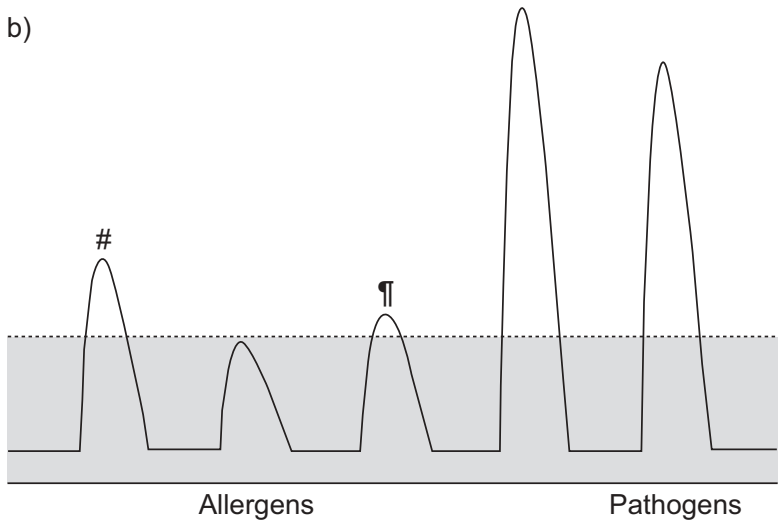

FIGURE 3. Schematic representation of the hypothetical effect of environment and gut microflora-induced T-regulatory (Treg) cell surveillance on the manifestation of allergic responses. a) In a less "hygienic" environment or in the case of a healthy, lactic acid bacteria-rich gut flora ( $\square$ ), the level of Treg cell surveillance (…......) is high enough to restrain manifestation of an allergen-specific T-cell activation. Pathogens generally surpass T-cell regulation in the first stages of infection by providing danger signals, resulting in T-cell-dependent adaptive immune responses aimed at eliminating the pathogen. b) In Western societies with high levels of hygiene and a disturbed composition of gut flora ( $\square$ ), Treg cell surveillance (….....) is decreased, so allowing development of conventional T cell-dependent allergen-specific responses, for instance increased levels of specific immunoglobulin E against a certain, relatively weak allergen (") or manifest symptoms of allergic disease induced by another allergen, which is more potent for the host $\left({ }^{\#}\right)$. Peaks denote the strength of specific T-cell responses to allergens or pathogens. Reprinted, with permission, from the Annual Review of Immunology, Volume 22 @) 2004 by Annual Reviews wnw.annualreviews.org.

protection against the development of atopy and atopic disease, the nature of stimulation of the immune system by intestinal pathogens is essential. Whereas all gastrointestinal pathogens are associated with food or personal hygiene, $H$. pylori and T. gondii differ from the others by generally establishing chronic interactions with their host. Treg cells are probably instrumental to this chronicity and were shown to be induced by $H$. pylori. These have not yet been demonstrated for $T$. gondii, but the observation that the in vitro CD4+ T cell hyporesponsiveness induced by this pathogen could be reversed with IL-2, points to the possible involvement of Treg cells [148]. The mechanism of the protective effect of hepatitis A virus, that does not induce a chronic infection, is probably different. It has been related to the presence of TIM-1, a specific receptor for this virus on CD4+ T cells, since carrying particular polymorphic variants of TIM-1 appeared strongly associated with protection against atopy, but only if carriers had serological evidence of past infection [149]. Therefore, it was suggested that hepatitis A virus would favourably change T-cell differentiation in carriers of the protective TIM-1 variants. Dependence of protection on these variants may also explain why some studies did not find an association between past hepatitis A virus infection and atopy [150, 151].

Inhibition of allergic responses by microbe-specific Tregs through the bystander suppression is not the only inhibitory mechanism. Microorganisms were also shown to act as an adjuvant to the induction of allergen-specific Treg cells. Treatment of ovalbumin-sensitised mice with a mixture of ovalbumin and heat-killed Listeria monocytogenes in incomplete Freund's adjuvant was shown to inhibit development of AHR or to reverse already established AHR. Moreover, it reduced airway inflammation, eosinophilia, mucus production, and antigen-specific $\operatorname{IgE}$ and IL-4 production, while increasing specific IFN- $\gamma$ production [152]. The inhibition was shown to be mediated by Th1-like Foxp3-expressing T cells, a novel type of aTregs [153]. In another mouse study, subcutaneous administration of the heat-killed saprophyte, Mycobacterium vaccae, in an aquous vehicle 3 weeks before intraperitoneal sensitisation with ovalbumin absorbed to alum inhibited subsequent induction of eosinophilic airway inflammation and AHR by respiratory ovalbumin challenge [154]. Effects have been attributed to ovalbumin-specific, CD4+CD45RBlow aTreg cells that mediated suppression by IL-10 and TGF- $\beta$ and CD11c+ APCs in lung tissue producing IL-10 and TGF- $\beta$, and IFN- $\alpha$ [155]. Although this approach is still far from being used as a practical application in humans, the demonstration that inhibitory allergen-specific Treg cells can be induced by means of a suitable adjuvant and treatment schedule holds promise for the future.

\section{T-REGULATORY CELLS AND ALLERGEN IMMUNOTHERAPY}

Although allergen immunotherapy has been practiced since 1911 [156], recent developments in purification of extracts and the general understanding of the mechanisms which bring about its action have increased its applicability and hold promise for improved, future treatment of allergic diseases. Allergen immunotherapy consists of repeated subcutaneous injections with increasing doses of allergen. It leads, in the majority of allergic patients, to a reduction of allergen-induced inflammation and allergic symptoms, reduced medication requirement, and a marked improvement in lung function, as has been summarised in a meta-analysis [157]. The clinical and anti-inflammatory effects of allergen-immunotherapy can last years after discontinuation, which makes this therapy the only current disease-modifying treatment for allergic diseases [158]. However, despite the efficacy of this classical form of therapy for the treatment of monoallergic asthma patients, it seldom results in complete alleviation of all asthma symptoms [157, $159,160]$. Moreover, in comparison with the easy to use and clinically very efficacious treatment with inhalation glucocorticoids, immunotherapy is hampered by side-effects at 


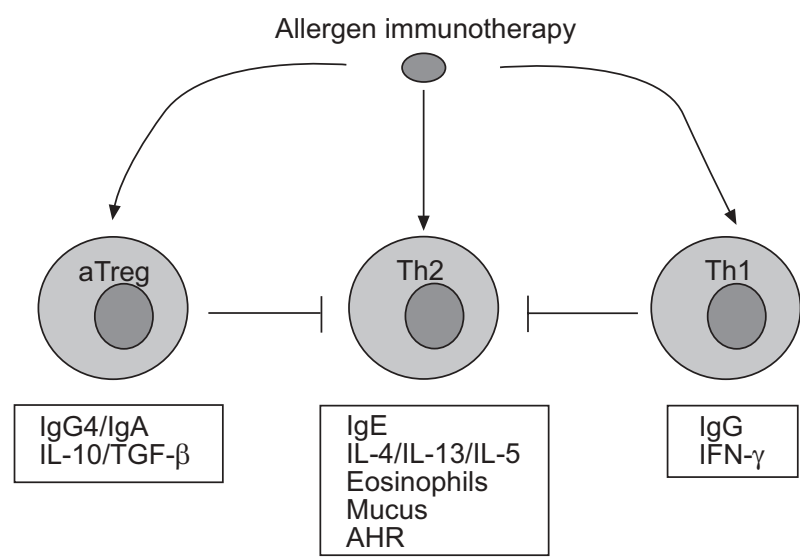

FIGURE 4. Immune deviation associated with the beneficial effects of allergen immunotherapy. After successful immunotherapy, increased serum levels of allergen-specific "blocking" immunoglobulin (Ig)G antibodies, in particular IgG4 and $\operatorname{IgA}$, are observed, whereas $\lg \mathrm{E}$ production is suppressed. The changes in serum I I isotypes are paralleled by a shift in allergen-specific T-cells from T-helper cells type 2 (Th2) to Th1 and the appearance of allergen-specific adaptive T-regulatory cells (aTreg: Th3 and T-regulatory cell type 1), characterised by an increased production of interferon (IFN)- $\gamma$, transforming growth factor (TGF) $\beta$ and interleukin (IL)-10, respectively. AHR: airway hyperresponsiveness. Copyright @ 2001 Massachusetts Medical Society. Adapted with permission from KAY et al. [163].

high allergen doses, especially in asthmatics and the necessity for frequent allergen injections over prolonged periods of time discourage physicians from applying immunotherapy on a large scale.

The beneficial effects of allergen immunotherapy are likely to be mediated through the reduction of allergen-induced inflammation. Immunological processes underlying these effects remain largely unknown at present, but several potential mechanisms have been postulated [161, 162]. As T cells orchestrate the inflammatory response, efforts since 1990 have been focused on activation and differentiation of $\mathrm{T}$ lymphocytes in relation to allergen immunotherapy. Both allergen-specific hyporeactivity and a shift in the cytokine profile of reacting T-lymphocytes (Th2 to Th1) have been proposed as underlying mechanism (fig. 4) [164-166]. In 1998, AKDIS et al. [167] were the first to provide evidence for a role of IL-10 and Tr1 cells in the beneficial effect of allergen immunotherapy in bee-venom allergic patients. They observed that the therapy-induced decrease in T-cell proliferation and production of IL-5 and IL-13 in response to bee-venom stimulation in vitro could be fully antagonised by neutralising IL-10. These data suggest an important role for IL-10producing $\operatorname{Tr} 1$ cells in allergen immunotherapy. Findings were extended by recent immunotherapy studies with airborne allergens that showed increases in allergen-specific IL-10producing $\operatorname{Tr} 1$ and TGF- $\beta$-producing Th3 type cells in the blood or airway tissue [168-170]. Whether the therapy-induced cytokines mediate the immunosuppressive effects remains unknown at present. Interestingly, in a mouse model of allergen immunotherapy [171], VISSERS et al. [172] recently demonstrated that blocking of the IL-10 receptor largely abrogated the beneficial effects of therapy, namely the reduction of bronchoalveolar lavage eosinophil numbers and AHR to methacholine.
In humans, increased IL-10 production after immunotherapy is not limited to $\mathrm{T}$ cells. B cells, monocytes and macrophages also produce this cytokine after immunotherapy [167, 168]. All three types can present antigen and by producing IL-10 they may be involved in the suppressive effects of immunotherapy, either directly or through the induction of $\operatorname{Tr} 1$ cells. In agreement herewith, it was recently demonstrated that antigen-pulsed macrophages suppress antigen-induced airway manifestations of asthma in an IL-10 dependent fashion [173]. IL-10 has been shown to decrease IgE production and to enhance $\mathrm{IgG}_{4}$ production in human B-lymphocytes in vitro. So, the immunotherapy-induced production of IL-10 by Tr1 cells may also be responsible for the observed increase in production of allergen-specific $\mathrm{IgG}_{4}$ antibodies [169, 174]. These antibodies may contribute to the immunosuppressive effects of immunotherapy by blocking IgE-facilitated antigenpresentation [169, 175]. In addition, at least in the mouse, immune-complexes of antigen and IgG may induce Fc $\gamma$ receptor-mediated IL-10 production by macrophages [176]. These data suggest a feedback stimulatory loop between IL-10, $\mathrm{IgG}_{4}$ and generation of $\operatorname{Tr} 1$ cells.

It can be concluded that the positive effects of allergen immunotherapy are associated with the appearance of $\operatorname{Tr} 1$ and Th3 cells (fig. 4). The mechanism by which these aTreg cells are induced by immunotherapy is presently unknown. However, if the details of this immunological pathway will be elucidated, novel strategies to improve immunotherapy may become available, not only for better treatment of allergic diseases, but also for efficient treatment of allergic asthma possibly with long-term improvement of disease. Welldescribed pathways to induce aTreg cells are antigen presentation to T-cells by immature DCs or the presence of IL-10 or TGF- $\beta$ in the local microenvironment. In this respect, combination of allergen immunotherapy with administration of compounds that inhibit DC maturation, such as $1,25(\mathrm{OH})_{2^{-}}$ VitD3 or glucocorticoids, may be an interesting strategy to pursue.

\section{CONCLUSION}

It is apparent that Treg cells may offer an explanation for many of the (pre)clinical observations that cannot be adequately explained by a disturbed Th1/Th2 balance. Although not yet studied extensively, data indicate that Treg cells interfere with the development of asthma and other allergic diseases at different stages, such as allergic sensitisation, progression to established allergic disease and asthma and severity and persistence of disease. Treg cells may also offer an explanation for the hygiene hypothesis. Microbial ligands can instruct DCs to become tolerogenic or immunogenic and likewise, induce protective Treg cells or diseases-inducing Th1 or Th2 cells. In addition, microbial ligands may directly promote nTreg cell function through TLRs or abrogate its function by inducing IL6 expression in DCs [73, 132, 177, 178]. At the basis of this complex and intriguing interaction between innate and adaptive immune responses, is the genetic background. Polymorphisms in TLR-2 and CD14 have been demonstrated to influence atopy and asthma susceptibility [136, 179-181]. In addition, polymorphisms of CTLA-4, which is important for nTreg cell function, have been associated with asthma [182-185]. 
Therapeutic opportunities to exploit the immunosuppressive effects of T-regulatory cells for prophylactic or therapeutic treatment and allergen immunotherapy may become feasible when current knowledge progresses. Although glucocorticoids appear to induce transient natural T-regulatory cells/Tregulatory type-1 like cells, stable induction may require additional, yet unknown, signals. Ex vivo generation and expansion of T-regulatory cells followed by autologous transfer is currently being explored for the treatment of autoimmune diseases and transplant rejection [98, 186-188]. When such treatment leads to long-term improvement of disease, it may be valuable to explore its application for the treatment of allergic asthma, in particular for those patients that are difficult to treat with currently available drugs. Alternatively, blocking the signals that restrain natural Tregulatory cell function, such as the natural ligand of GITR and interleukin-6 may potentiate the suppressive function of natural T-regulatory cells in vivo.

Note added in proof: it is now feasible to determine intracellular FOXP3 protein expression by flow cytometry in order to directly identify nTreg cells [189].

\section{REFERENCES}

1 Coyle AJ, Gutierrez-Ramos JC. The role of ICOS and other costimulatory molecules in allergy and asthma. Springer Semin Immunopathol 2004; 25: 349-359.

2 Romagnani S. The role of lymphocytes in allergic disease. J Allergy Clin Immunol 2000; 105: 399-408.

3 Larche M, Robinson DS, Kay AB. The role of $\mathrm{T}$ lymphocytes in the pathogenesis of asthma. J Allergy Clin Immunol 2003; 111: 450-463.

4 Mosmann TR, Coffman RL. TH1 and TH2 cells: different patterns of lymphokine secretion lead to different functional properties. Ann Rev Immunol 1989; 7: 145-173.

5 Kapsenberg ML, Jansen HM, Bos JD, Wierenga EA. Role of type 1 and type $2 \mathrm{~T}$ helper cells in allergic diseases. Curr Opin Immunol 1992; 4: 788-793.

6 Romagnani S. Human TH1 and TH2 subsets: regulation of differentiation and role in protection and immunopathology. Int Arch Allergy Immunol 1992; 98: 279-285.

7 Herrick CA, Bottomly K. To respond or not to respond: T cells in allergic asthma. Nat Rev Immunol 2003; 3: 405-412.

8 Wills-Karp M, Santeliz J, Karp CL. The germless theory of allergic disease: revisiting the hygiene hypothesis. Nature Rev Immunol 2001; 1: 69-75.

9 Gor DO, Rose NR, Greenspan NS. T $\mathrm{T}_{\mathrm{H}} 1-\mathrm{T}_{\mathrm{H}} 2$ : a Procrustean paradigm. Nat Immunol 2003; 4: 503-505.

10 Hansen G, Berry G, Dekruyff RH, Umetsu DT. Allergenspecific Th1 cells fail to counterbalance Th2 cell-induced airway hyperreactivity but cause severe airway inflammation. J Clin Invest 1999; 103: 175-183.

11 Ford JG, Rennick D, Donaldson DD, et al. IL-13 and IFN$\gamma$ : interactions in lung inflammation. J Immunol 2001; 167: 1769-1777.

12 Dahl ME, Dabbagh K, Liggitt D, Kim S, Lewis DB. Viralinduced $\mathrm{T}$ helper type 1 responses enhance allergic disease by effects on lung dendritic cells. Nat Immunol 2004; 5: 337-343.
13 Hessel EM, Van Oosterhout AJM, Van Ark I, et al. Development of airway hyperresponsiveness is dependent on IFN- $\gamma$ and independent of eosinophil infiltration. Am J Respir Cell Mol Biol 1997; 16: 325-335.

14 Heaton T, Rowe J, Turner S, et al. An immunoepidemiological approach to asthma: identification of in-vitro T-cell response patterns associated with different wheezing phenotypes in children. Lancet 2005; 365: 142-149.

15 Rowe J, Heaton T, Kusel M, et al. High IFN- $\gamma$ production by $\mathrm{CD}^{+} \mathrm{T}$ cells and early sensitization among infants at high risk of atopy. J Allergy Clin Immunol 2004; 113: 710-716.

16 Holtzman MJ, Sampath D, Castro M, Look DC, Jayaraman S. The one-two of $\mathrm{T}$ helper cells: does interferon- $\gamma$ knock out the Th2 hypothesis for asthma? Am J Respir Cell Mol Biol 1996; 14: 316-318.

17 Krug N, Madden J, Redington AE, et al. T-cell cytokine profile evaluated at the single cell level in BAL and blood in allergic asthma. Am J Respir Cell Mol Biol 1996; 14: 319-326.

18 Grewe M, Bruijnzeel-Koomen CA, Schopf E, et al. A role for Th1 and Th2 cells in the immunopathogenesis of atopic dermatitis. Immunol Today 1998; 19: 359-361.

19 Yazdanbakhsh M, Kremsner PG, van Ree R. Allergy, parasites, and the hygiene hypothesis. Science 2002; 296: 490-494.

20 Sheikh A, Smeeth L, Hubbard R. There is no evidence of an inverse relationship between TH2-mediated atopy and TH1-mediated autoimmune disorders: lack of support for the hygiene hypothesis. J Allergy Clin Immunol 2003; 111: 131-135.

21 Bach JF. The effect of infections on susceptibility to autoimmune and allergic diseases. N Engl J Med 2002; 347: 911-920.

22 Shevach EM. CD4 ${ }^{+} \mathrm{CD}_{2} 5^{+}$suppressor T cells: more questions than answers. Nat Rev Immunol 2002; 2: 389-400.

23 Maloy KJ, Powrie F. Regulatory T cells in the control of immune pathology. Nat Immunol 2001; 2: 816-822.

24 Fehervari Z, Sakaguchi S. Development and function of $\mathrm{CD} 25^{+} \mathrm{CD} 4^{+}$regulatory T cells. Curr Opin Immunol 2004; 16: 203-208.

25 Zou L, Barnett B, Safah H, et al. Bone marrow is a reservoir for $\mathrm{CD} 4^{+} \mathrm{CD} 25^{+}$regulatory $\mathrm{T}$ cells that traffic through CXCL12/CXCR4 signals. Cancer Res 2004; 64 8451-8455.

26 Thornton AM, Shevach EM. Suppressor effector function of $\mathrm{CD}^{+} \mathrm{CD} 25^{+}$immunoregulatory $\mathrm{T}$ cells is antigen nonspecific. J Immunol 2000; 164: 183-190.

27 Bluestone JA, Abbas AK. Opinion-regulatory lymphocytes: natural versus adaptive regulatory T cells. Nat Rev Immunol 2003; 3: 253-257.

28 Hsieh CS, Liang Y, Tyznik AJ, Self SG, Liggitt D, Rudensky AY. Recognition of the peripheral self by naturally arising $\mathrm{CD} 25^{+} \mathrm{CD} 4^{+} \mathrm{T}$ cell receptors. Immunity 2004; 21: 267-277.

29 Jordan MS, Boesteanu A, Reed AJ, et al. Thymic selection of $\mathrm{CD} 4{ }^{+} \mathrm{CD} 25^{+}$regulatory $\mathrm{T}$ cells induced by an agonist self-peptide. Nat Immunol 2001; 2: 301-306.

30 Mills KH. Regulatory T cells: friend or foe in immunity to infection? 2004; 4: 841-855. 
31 Apostolou I, Von Boehmer H. In vivo instruction of suppressor commitment in naive T cells. J Exp Med 2004; 199: 1401-1408.

32 Huber S, Schramm C, Lehr HA, et al. Cutting edge: TGF- $\beta$ signaling is required for the in vivo expansion and immunosuppressive capacity of regulatory $\mathrm{CD} 4{ }^{+} \mathrm{CD} 25^{+}$ T cells. J Immunol 2004; 173: 6526-6531.

33 Fantini MC, Becker C, Monteleone G, Pallone F, Galle PR, Neurath MF. Cutting edge: TGF- $\beta$ induces a regulatory phenotype in CD4+CD25- T cells through Foxp3 induction and down-regulation of Smad7. J Immunol 2004; 172: 5149-5153.

34 Chen W, Jin W, Hardegen N, et al. Conversion of peripheral $\mathrm{CD}_{4}^{+} \mathrm{CD} 25^{-}$naive $\mathrm{T}$ cells to $\mathrm{CD} 4^{+} \mathrm{CD} 25^{+}$ regulatory $\mathrm{T}$ cells by TGF- $\beta$ induction of transcription factor Foxp3. J Exp Med 2003; 198: 1875-1886.

35 Karagiannidis C, Akdis M, Holopainen $\mathrm{P}$, et al. Glucocorticoids upregulate FOXP3 expression and regulatory T cells in asthma. J Allergy Clin Immunol 2004; 114 : 1425-1433.

36 Sakaguchi S. Regulatory T cells: key controllers of immunologic self-tolerance. Cell 2000; 101: 455-458.

37 Stassen M, Fondel S, Bopp T, et al. Human CD25 regulatory $\mathrm{T}$ cells: two subsets defined by the integrins $\alpha 4 \beta 7$ or $\alpha 4 \beta 1$ confer distinct suppressive properties upon $\mathrm{CD}^{+} \mathrm{T}$ helper cells. Eur J Immunol 2004; 34: 1303-1311.

38 Dieckmann D, Bruett $\mathrm{CH}$, Ploettner $\mathrm{H}$, Lutz $\mathrm{MB}$, Schuler G. Human $\mathrm{CD}^{+} \mathrm{CD} 25^{+}$regulatory, contactdependent $\mathrm{T}$ cells induce interleukin 10-producing, contact-independent type 1-like regulatory T cells. J Exp Med 2002; 196: 247-253.

39 Foussat A, Cottrez F, Brun V, Fournier N, Breittmayer JP, Groux $\mathrm{H}$. A comparative study between $\mathrm{T}$ regulatory type 1 and $\mathrm{CD}^{+} \mathrm{CD} 25^{+} \mathrm{T}$ cells in the control of inflammation. J Immunol 2003; 171: 5018-5026.

40 Zheng SG, Wang JH, Gray JD, Soucier H, Horwitz DA. Natural and induced $\mathrm{CD} 4{ }^{+} \mathrm{CD} 25^{+}$cells educate CD4+CD25- cells to develop suppressive activity: the role of IL-2, TGF- $\beta$, and IL-10. J Immunol 2004; 172: 5213-5221.

41 Birebent $B$, Lorho $\mathrm{R}$, Lechartier $\mathrm{H}$, et al. Suppressive properties of human $\mathrm{CD} 4{ }^{+} \mathrm{CD} 25^{+}$regulatory $\mathrm{T}$ cells are dependent on CTLA-4 expression. Eur J Immunol 2004; 34 : 3485-3496.

42 Read S, Malmstrom V, Powrie F. Cytotoxic T lymphocyte-associated antigen 4 plays an essential role in the function of $\mathrm{CD} 25^{+} \mathrm{CD} 4^{+}$regulatory cells that control intestinal inflammation. J Exp Med 2000; 192: 295-302.

43 Anastasi E, Campese AF, Bellavia D, et al. Expression of activated notch3 in transgenic mice enhances generation of $\mathrm{T}$ regulatory cells and protects against experimental autoimmune diabetes. J Immunol 2003; 171: 4504-4511.

44 Huang CT, Workman CJ, Flies D, et al. Role of LAG-3 in regulatory T cells. Immunity 2004; 21: 503-513.

45 Pae HO, Oh GS, Choi BM, Chae SC, Chung HT. Differential expressions of heme oxygenase-1 gene in CD25- and CD25 $5^{+}$subsets of human CD4+ T cells. Biochem Biophys Res Commun 2003; 306: 701-705.

46 Munn DH, Sharma MD, Mellor AL. Ligation of B7-1/B72 by human $\mathrm{CD}^{+} \mathrm{T}$ cells triggers indoleamine 2,3-dioxygenase activity in dendritic cells. I Immunol 2004; 172: 4100-4110.

47 Mellor AL, Baban B, Chandler $\mathrm{P}$, et al. Cutting edge: induced indoleamine 2,3 dioxygenase expression in dendritic cell subsets suppresses T cell clonal expansion. J Immunol 2003; 171: 1652-1655.

48 Grohmann U, Fallarino F, Puccetti P. Tolerance, DCs and tryptophan: much ado about IDO. Trends Immunol 2003; 24: 242-248.

49 Mellor AL, Munn DH. IDO expression by dendritic cells: tolerance and tryptophan catabolism. Nat Rev Immunol 2004; 4: 762-774.

50 Logue EC, Sha WC. CD28-B7 bidirectional signaling: a two-way street to activation. Nat Immunol 2004; 5: 1103-1105.

51 Orabona C, Grohmann U, Belladonna ML, et al. CD28 induces immunostimulatory signals in dendritic cells via CD80 and CD86. Nat Immunol 2004; 5: 1134-1142.

52 Baecher-Allan C, Brown JA, Freeman GJ, Hafler DA. $\mathrm{CD} 4^{+} \mathrm{CD} 25$ high regulatory cells in human peripheral blood. J Immunol 2001; 167: 1245-1253.

53 Bruder D, Probst-Kepper M, Westendorf AM, et al. Neuropilin-1: a surface marker of regulatory T cells. Eur J Immunol 2004; 34: 623-630.

54 Lehmann J, Huehn J, De La Rosa M, et al. Expression of the integrin $\alpha E \beta 7$ identifies unique subsets of $\mathrm{CD}_{2} 5^{+}$as well as CD25- regulatory T cells. Proc Natl Acad Sci USA 2002; 99: 13031-13036.

55 Huehn J, Siegmund K, Lehmann JC, et al. Developmental stage, phenotype, and migration distinguish naive- and effector/memory-like $\mathrm{CD} 4^{+}$regulatory T cells. J Exp Med 2004; 199: 303-313.

56 Wahl SM, Vazquez N, Chen W. Regulatory T cells and transcription factors: gatekeepers in allergic inflammation. Curr Opin Immunol 2004; 16: 768-774.

57 Walker MR, Kasprowicz DJ, Gersuk VH, et al. Induction of FoxP3 and acquisition of $\mathrm{T}$ regulatory activity by stimulated human CD4 ${ }^{+}$CD25- T cells. J Clin Invest 2003; 112: 1437-1443.

58 Hori S, Nomura T, Sakaguchi S. Control of regulatory T cell development by the transcription factor FOXP3. Science 2003; 299: 1057-1061.

59 Fontenot JD, Gavin MA, Rudensky AY. Foxp3 programs the development and function of $\mathrm{CD} 4{ }^{+} \mathrm{CD} 25^{+}$regulatory T cells. Nat Immunol 2003; 4: 330-336.

60 Khattri R, Cox T, Yasayko SA, Ramsdell F. An essential role for Scurfin in $\mathrm{CD} 4{ }^{+} \mathrm{CD} 25^{+} \mathrm{T}$ regulatory cells. Nat Immunol 2003; 4: 337-342.

61 Yagi H, Nomura T, Nakamura K, et al. Crucial role of FOXP3 in the development and function of human $\mathrm{CD} 25^{+} \mathrm{CD} 4^{+}$regulatory $\mathrm{T}$ cells. Int Immunol 2004; 16: 1643-1656.

62 De Jong EC, Smits HH, Kapsenberg ML. Dendritic cellmediated T cell polarization. Springer Semin Immunopathol 2005; 26: 289-307.

63 Cottrez F, Groux H. Regulation of TGF- $\beta$ response during $\mathrm{T}$ cell activation is modulated by IL-10. J Immunol 2001; 167: 773-778.

64 Kitani A, Fuss I, Nakamura K, Kumaki F, Usui T, Strober W. Transforming growth factor (TGF)- $\beta 1$ producing regulatory $\mathrm{T}$ cells induce smad-mediated 
interleukin 10 secretion that facilitates coordinated immunoregulatory activity and amelioration of TGF- $\beta 1$ mediated fibrosis. J Exp Med 2003; 13: 13.

65 Kapsenberg ML. Dendritic-cell control of pathogendriven T-cell polarization. Nat Rev Immunol 2003; 3: 984-993.

66 Lambrecht BN, Hammad H. Taking our breath away: dendritic cells in the pathogenesis of asthma. Nat Rev Immunol 2003; 3: 994-1003.

67 Pulendran B, Palucka K, Banchereau J. Sensing pathogens and tuning immune responses. Science 2001; 293: 253-256.

68 Reis e Sousa C. Dendritic cells as sensors of infection. Immunity 2001; 14: 495-498.

69 Wagner H. Toll meets bacterial cpg-dna. Immunity 2001; 14: 499-502.

70 van Kooyk Y, Engering A, Lekkerkerker AN, Ludwig IS, Geijtenbeek TB. Pathogens use carbohydrates to escape immunity induced by dendritic cells. Curr Opin Immunol 2004; 16: 488-493.

71 Aderem A, Ulevitch RJ. Toll-like receptors in the induction of the innate immune response. Nature 2000, 406: 782-787.

72 Pasare C, Medzhitov R. Toll-dependent control mechanisms of CD4 T cell activation. Immunity 2004; 21: 733-741.

73 Lutz MB, Schuler G. Immature, semi-mature and fully mature dendritic cells: which signals induce tolerance or immunity? Trends Immunol 2002; 23: 445-449.

74 Dhodapkar MV, Steinman RM, Krasovsky J, Munz C, Bhardwaj N. Antigen-specific inhibition of effector T cell function in humans after injection of immature dendritic cells. J Exp Med 2001; 193: 233-238.

75 Jonuleit H, Schmitt E, Steinbrink K, Enk AH. Dendritic cells as a tool to induce anergic and regulatory $\mathrm{T}$ cells. Trends Immunol 2001; 22: 394-400.

76 Roncarolo MG, Levings MK, Traversari C. Differentiation of $\mathrm{T}$ regulatory cells by immature dendritic cells. J Exp Med 2001; 193: F5-F10.

77 Dong X, Craig T, Xing N, et al. Direct transcriptional regulation of RelB by $1 \alpha, 25$-dihydroxyvitamin D3 and its analogs: physiologic and therapeutic implications for dendritic cell function. J Biol Chem 2003; 278: 49378-49385.

78 Gregori S, Casorati M, Amuchastegui S, Smiroldo S, Davalli AM, Adorini L. Regulatory T cells induced by 1 , 25-dihydroxyvitamin D3 and mycophenolate mofetil treatment mediate transplantation tolerance. J Immunol 2001; 167: 1945-1953.

79 Gregori S, Giarratana N, Smiroldo S, Uskokovic M, Adorini L. A 1 1 ,25-dihydroxyvitamin $\mathrm{D}(3)$ analog enhances regulatory $\mathrm{T}$-cells and arrests autoimmune diabetes in NOD mice. Diabetes 2002; 51: 1367-1374.

80 Barrat FJ, Cua DJ, Boonstra A, et al. In vitro generation of interleukin 10-producing regulatory $\mathrm{CD}^{+} \mathrm{T}$ cells is induced by immunosuppressive drugs and inhibited by T helper type 1 (Th1)- and Th2-inducing cytokines. J Exp Med 2002; 195: 603-616.

81 Weiner HL. The mucosal milieu creates tolerogenic dendritic cells and TR1 and TH3 regulatory cells. Nat Immunol 2001; 2: 671-672.

82 Akbari O, DeKruyff RH, Umetsu DT. Pulmonary dendritic cells producing IL-10 mediate tolerance induced by respiratory exposure to antigen. Nat Immunol 2001; 2: 725-731.

83 Akbari O, Freeman GJ, Meyer EH, et al. Antigen-specific regulatory $\mathrm{T}$ cells develop via the ICOS:ICOS-ligand pathway and inhibit allergen-induced airway hyperreactivity. Nat Med 2002; 8: 1024-1032

84 Sudo N, Sawamura S, Tanaka K, Aiba Y, Kubo C, Koga Y. The requirement of intestinal bacterial flora for the development of an IgE production system fully susceptible to oral tolerance induction. J Immunol 1997; 159: 1739-1745.

85 Mowat AM. Anatomical basis of tolerance and immunity to intestinal antigens. Nat Rev Immunol 2003; 3: 331-341.

86 Tanaka K, Ishikawa H. Role of intestinal bacterial flora in oral tolerance induction. Histol Histopathol 2004; 19: 907-914.

87 Kelly D, Campbell JI, King TP, et al. Commensal anaerobic gut bacteria attenuate inflammation by regulating nuclear-cytoplasmic shuttling of PPAR- $\gamma$ and RelA. Nat Immunol 2004; 5: 104-112.

88 Beg AA. ComPPARtmentalizing NF- $\kappa$ B in the gut. Nat Immunol 2004; 5: 14-16.

89 Steinman RM, Hawiger D, Nussenzweig MC. Tolerogenic dendritic cells. Annu Rev Immunol 2003; 21: 685-711.

90 Holt PG, Macaubas C, Prescott SL, Sly PD. Primary sensitization to inhalant allergens. Am J Respir Crit Care Med 2000; 162: S91-S94.

91 Holt PG, Rowe J, Loh R, Sly PD. Developmental factors associated with risk for atopic disease: implications for vaccine strategies in early childhood. Vaccine 2003; 21: 3432-3435.

92 Prescott SL, Macaubas C, Holt BJ, et al. Transplacental priming of the human immune system to enviromental allergens: universal skewing of initial $\mathrm{T}$ cell responses toward the Th2 cytokine profile. J Immun 1998; 160: 4730-4737.

93 Prescott SL, Macaubas C, Smallacombe T, Holt BJ, Sly PD, Holt PG. Development of allergen-specific T-cell memory in atopic and normal children. Lancet 1999; 353: 196-200.

94 Takahata $\mathrm{Y}$, Nomura A, Takada $\mathrm{H}$, et al. CD $25^{+} \mathrm{CD} 4^{+} \mathrm{T}$ cells in human cord blood: an immunoregulatory subset with naive phenotype and specific expression of forkhead box p3 (Foxp3) gene. Exp Hematol 2004; 32: 622-629.

95 Thornton CA, Upham JW, Wikstrom ME, et al. Functional maturation of $\mathrm{CD} 4{ }^{+} \mathrm{CD} 25^{+} \mathrm{CTLA} 4^{+} \mathrm{CD} 45 \mathrm{RA}^{+} \mathrm{T}$ regulatory cells in human neonatal $\mathrm{T}$ cell responses to environmental antigens/allergens. J Immunol 2004; 173: 3084-3092.

96 Bellinghausen I, Klostermann B, Knop J, Saloga J. Human CD4CD25 $\mathrm{T}$ cells derived from the majority of atopic donors are able to suppress $\mathrm{TH} 1$ and $\mathrm{TH} 2$ cytokine production. J Allergy Clin Immunol 2003; 111: 862-868.

97 Ling EM, Smith T, Nguyen XD, et al. Relation of CD4+CD25+ regulatory T-cell suppression of allergendriven T-cell activation to atopic status and expression of allergic disease. Lancet 2004; 363: 608-615.

98 Sakaguchi S. Naturally arising $\mathrm{CD}^{+}$regulatory T cells for immunologic self-tolerance and negative control of immune responses. Annu Rev Immunol 2004; 22: 531-562. 
99 Karlsson MR, Rugtveit J, Brandtzaeg P. Allergenresponsive $\mathrm{CD} 4{ }^{+} \mathrm{CD} 25^{+}$regulatory $\mathrm{T}$ cells in children who have outgrown cow's milk allergy. J Exp Med 2004; 199: 1679-1688.

100 Matsumoto K, Inoue H, Fukuyama S, et al. Decrease of interleukin-10-producing $\mathrm{T}$ cells in the peripheral blood of severe unstable atopic asthmatics. Int Arch Allergy Immunol 2004; 134: 295-302.

101 Akdis M, Verhagen J, Taylor A, et al. Immune responses in healthy and allergic individuals are characterized by a fine balance between allergen-specific T regulatory 1 and T helper 2 cells. J Exp Med 2004; 199: 1567-1575.

102 Dao Nguyen X, Robinson DS. Fluticasone propionate increases CD4CD25 $\mathrm{T}$ regulatory cell suppression of allergen-stimulated CD4CD25 $\mathrm{T}$ cells by an IL-10dependent mechanism. J Allergy Clin Immunol 2004; 114: 296-301.

103 Verhasselt V, Vosters O, Beuneu C, Nicaise C, Stordeur P, Goldman M. Induction of FOXP3-expressing regulatory CD4pos $\mathrm{T}$ cells by human mature autologous dendritic cells. Eur J Immunol 2004; 34: 762-772.

104 Suto A, Nakajima H, Kagami SI, Suzuki K, Saito Y, Iwamoto I. Role of $\mathrm{CD} 4{ }^{+} \mathrm{CD} 25^{+}$regulatory $\mathrm{T}$ cells in $\mathrm{T}$ helper 2 cell-mediated allergic inflammation in the airways. Am J Respir Crit Care Med 2001; 164: 680-687.

105 Curotto de Lafaille MA, Muriglan S, Sunshine MJ, et al. Hyper immunoglobulin E response in mice with monoclonal populations of B and T lymphocytes. J Exp Med 2001; 194: 1349-1359.

106 Hadeiba H, Locksley RM. Lung CD25 CD4 regulatory T cells suppress type 2 immune responses but not bronchial hyperreactivity. J Immunol 2003; 170: 5502-5510.

107 Jaffar Z, Sivakuru T, Roberts K. CD4 ${ }^{+} \mathrm{CD} 25^{+} \mathrm{T}$ cells regulate airway eosinophilic inflammation by modulating the Th2 cell phenotype. J Immunol 2004; 172: 3842-3849.

108 Van Oosterhout AJM, Van Esch ECAM, Deurloo DT, Vissers JL. Natural regulatory T-cells limit allergeninduced airway hyperreactivity and IgE production in mice. Am J Respir Crit Care Med 2004; 169: A702.

109 Shimizu J, Yamazaki S, Takahashi T, Ishida Y, Sakaguchi S. Stimulation of $\mathrm{CD} 25^{+} \mathrm{CD} 4^{+}$regulatory $\mathrm{T}$ cells through GITR breaks immunological self-tolerance. Nat Immunol 2002; 3: 135-142.

110 Stephens GL, McHugh RS, Whitters MJ, et al. Engagement of glucocorticoid-induced TNFR familyrelated receptor on effector $\mathrm{T}$ cells by its ligand mediates resistance to suppression by $\mathrm{CD}^{+} \mathrm{CD} 25^{+} \mathrm{T}$ cells. $J$ Immunol 2004; 173: 5008-5020.

111 Ronchetti S, Zollo O, Bruscoli S, et al. GITR, a member of the TNF receptor superfamily, is costimulatory to mouse T lymphocyte subpopulations. Eur J Immunol 2004; 34: 613-622.

112 Kohm AP, Williams JS, Miller SD. Cutting edge: ligation of the glucocorticoid-induced TNF receptor enhances autoreactive $\mathrm{CD}^{+} \mathrm{T}$ cell activation and experimental autoimmune encephalomyelitis. J Immunol 2004; 172: 4686-4690.

113 Kanamaru F, Youngnak $\mathrm{P}$, Hashiguchi M, et al. Costimulation via glucocorticoid-induced TNF receptor in both conventional and $\mathrm{CD} 25+$ regulatory $\mathrm{CD}^{+} \mathrm{T}$ cells. J Immunol 2004; 172: 7306-7314.

114 Tone M, Tone Y, Adams E, et al. Mouse glucocorticoidinduced tumor necrosis factor receptor ligand is costimulatory for T cells. Proc Natl Acad Sci USA 2003; 100: 15059-15064.

115 Shin H, Kwon B, Choi H. Recombinant glucocorticoid induced tumour necrosis factor receptor (rGITR) induced cox-2 activity in murine macrophage Raw 264.7 cells. Cytokine 2002; 19: 187.

116 Shin HH, Lee MH, Kim SG, Lee YH, Kwon BS, Choi HS. Recombinant glucocorticoid induced tumor necrosis factor receptor (rGITR) induces NOS in murine macrophage. FEBS Lett 2002; 514: 275-280.

117 Yu KY, Kim HS, Song SY, Min SS, Jeong JJ, Youn BS. Identification of a ligand for glucocorticoid-induced tumor necrosis factor receptor constitutively expressed in dendritic cells. Biochem Biophys Res Commun 2003; 310: 433-438.

118 Akbari O, Stock P, DeKruyff RH, Umetsu DT. Mucosal tolerance and immunity: regulating the development of allergic disease and asthma. Int Arch Allergy Immunol 2003; 130: 108-118.

119 Holt PG, Batty JE, Turner KJ. Inhibition of specific IgE responses in mice by pre-exposure to inhaled antigen. Immunology 1981; 42: 409-417.

120 Hurst SD, Seymour BW, Muchamuel T, Kurup VP, Coffman RL. Modulation of inhaled antigen-induced IgE tolerance by ongoing Th2 responses in the lung. $J$ Immunol 2001; 166: 4922-4930.

121 Tsitoura DC, Blumenthal RL, Berry G, Dekruyff RH, Umetsu DT. Mechanisms preventing allergen-induced airways hyperreactivity: role of tolerance and immune deviation. J Allergy Clin Immunol 2000; 106: 239-246.

122 Samsom JN. Regulation of antigen-specific regulatory Tcell induction via nasal and oral mucosa. Crit Rev Immunol 2004; 24: 157-177.

123 Ostroukhova M, Seguin-Devaux C, Oriss TB, et al. Tolerance induced by inhaled antigen involves $\mathrm{CD}^{+} \mathrm{T}$ cells expressing membrane-bound TGF- $\beta$ and FOXP3. $J$ Clin Invest 2004; 114: 28-38.

124 Johnson JR, Wiley RE, Fattouh R, et al. Continuous exposure to house dust mite elicits chronic airway inflammation and structural remodeling. Am J Respir Crit Care Med 2003; 3: 3.

125 Cates EC, Gajewska BU, Goncharova S, et al. Effect of GM-CSF on immune, inflammatory, and clinical responses to ragweed in a novel mouse model of mucosal sensitization. J Allergy Clin Immunol 2003; 111: 1076-1086.

126 Cates EC, Fattouh R, Wattie J, et al. Intranasal exposure of mice to house dust mite elicits allergic airway inflammation via a GM-CSF-mediated mechanism. J Immunol 2004; 173: 6384-6392.

127 Stampfli MR, Wiley RE, Neigh GS, et al. GM-CSF transgene expression in the airway allows aerosolized ovalbumin to induce allergic sensitization in mice. J Clin Invest 1998; 102: 1704-1714.

128 Sun G, Stacey MA, Schmidt M, Mori L, Mattoli S. Interaction of mite allergens der p3 and der p9 with 
protease-activated receptor-2 expressed by lung epithelial cells. J Immunol 2001; 167: 1014-1021.

129 Kheradmand F, Kiss A, Xu J, Lee SH, Kolattukudy PE, Corry DB. A protease-activated pathway underlying Th cell type 2 activation and allergic lung disease. J Immunol 2002; 169: 5904-5911.

130 King C, Brennan S, Thompson PJ, Stewart GA. Dust mite proteolytic allergens induce cytokine release from cultured airway epithelium. J Immunol 1998; 161: 3645-3651.

131 Gough L, Schulz O, Sewell HF, Shakib F. The cysteine protease activity of the major dust mite allergen der $\mathrm{p} 1$ selectively enhances the immunoglobulin E antibody response. J Exp Med 1999; 190: 1897-1902.

132 Kubo T, Hatton RD, Oliver J, Liu X, Elson CO, Weaver CT. Regulatory $\mathrm{T}$ cell suppression and anergy are differentially regulated by proinflammatory cytokines produced by TLR-activated dendritic cells. J Immunol 2004; 173: 7249-7258.

133 Gilliet $\mathrm{M}$, Soumelis V, Watanabe $\mathrm{N}$, et al. Human dendritic cells activated by TSLP and CD40L induce proallergic cytotoxic T cells. J Exp Med 2003; 197: 1059-1063.

134 Soumelis V, Reche PA, Kanzler H, et al. Human epithelial cells trigger dendritic cell mediated allergic inflammation by producing TSLP. Nat Immunol 2002; 3: 673-680.

135 Soumelis V, Liu YJ. Human thymic stromal lymphopoietin: a novel epithelial cell-derived cytokine and a potential key player in the induction of allergic inflammation. Springer Semin Immunopathol 2004; 25: 325-333.

136 Rook GA, Martinelli R, Brunet LR. Innate immune responses to mycobacteria and the downregulation of atopic responses. Curr Opin Allergy Clin Immunol 2003; 3: 337-342.

137 Mazzoni A, Segal DM. Controlling the toll road to dendritic cell polarization. J Leukoc Biol 2004; 75: 721-730.

138 Maizels RM, Balic A, Gomez-Escobar N, Nair M, Taylor MD, Allen JE. Helminth parasites-masters of regulation. Immunol Rev 2004; 201: 89-116.

139 Belkaid Y, Piccirillo CA, Mendez S, Shevach EM, Sacks DL. CD4+CD25+ regulatory $\mathrm{T}$ cells control leishmania major persistence and immunity. Nature 2002; 420: 502-507.

140 Von Herrath MG, Harrison LC. Regulatory lymphocytes: antigen-induced regulatory $\mathrm{T}$ cells in autoimmunity. Nat Rev Immunol 2003; 3: 223-232.

141 Rook GA, Adams V, Hunt J, Palmer R, Martinelli R, Brunet LR. Mycobacteria and other environmental organisms as immunomodulators for immunoregulatory disorders. Springer Semin Immunopathol 2004; 25: 237-255.

142 Gad M, Pedersen AE, Kristensen NN, Claesson MH. Demonstration of strong enterobacterial reactivity of $\mathrm{CD}^{+} \mathrm{CD} 25^{-} \mathrm{T}$ cells from conventional and germ-free mice which is counter-regulated by $\mathrm{CD} 4^{+} \mathrm{CD} 25^{+} \mathrm{T}$ cells. Eur J Immunol 2004; 34: 695-704.

143 Kalliomaki M, Isolauri E. Role of intestinal flora in the development of allergy. Curr Opin Allergy Clin Immunol 2003; 3: 15-20.

144 Hattori K, Yamamoto A, Sasai M, et al. Effects of administration of bifidobacteria on fecal microflora and clinical symptoms in infants with atopic dermatitis Arerugi 2003; 52: 20-30.

145 Bjorksten B. Effects of intestinal microflora and the environment on the development of asthma and allergy. Springer Semin Immunopathol 2004; 25: 257-270.

146 Matricardi PM, Rosmini F, Riondino S, et al. Exposure to foodborne and orofecal microbes versus airborne viruses in relation to atopy and allergic asthma: epidemiological study. BMJ 2000; 320: 412-417.

147 Linneberg A, Ostergaard C, Tvede $\mathrm{M}$, et al. IgG antibodies against microorganisms and atopic disease in Danish adults: the Copenhagen Allergy Study. J Allergy Clin Immunol 2003; 111: 847-853.

148 Voisin MB, Buzoni-Gatel D, Bout D, Velge-Roussel F. Both expansion of regulatory $\mathrm{GR} 1^{+} \mathrm{CD} 11 \mathrm{~b}^{+}$myeloid cells and anergy of $\mathrm{T}$ lymphocytes participate in hyporesponsiveness of the lung-associated immune system during acute toxoplasmosis. Infect Immun 2004; 72: 5487-5492.

149 McIntire JJ, Umetsu DT, DeKruyff RH. TIM-1, a novel allergy and asthma susceptibility gene. Springer Semin Immunopathol 2004; 25: 335-348.

150 Gonzalez-Quintela A, Gude F, Boquete O, et al. Association of hepatitis A virus infection with allergic sensitization in a population with high prevalence of hepatitis A virus exposure. Allergy 2005; 60: 98-103.

151 Uter W, Stock C, Pfahlberg A, et al. Association between infections and signs and symptoms of "atopic" hypersensitivity-results of a cross-sectional survey among first-year university students in Germany and Spain. Allergy 2003; 58: 580-584.

152 Hansen G, Yeung VP, Berry G, Umetsu DT, DeKruyff RH. Vaccination with heat-killed listeria as adjuvant reverses established allergen-induced airway hyperreactivity and inflammation: role of $\mathrm{CD}^{+} \mathrm{T}$ cells and IL-18. J Immunol 2000; 164: 223-230.

153 Stock P, Akbari O, Berry G, Freeman GJ, Dekruyff RH, Umetsu DT. Induction of T helper type 1-like regulatory cells that express Foxp3 and protect against airway hyperreactivity. Nat Immunol 2004; 5: 1149-1156.

154 Zuany-Amorim C, Sawicka E, Manlius C, et al. Suppression of airway eosinophilia by killed Mycobacterium vaccae-induced allergen-specific regulatory T-cells. Nat Med 2002; 8: 625-629.

155 Adams VC, Hunt JR, Martinelli R, Palmer R, Rook GA, Brunet LR. Mycobacterium vaccae induces a population

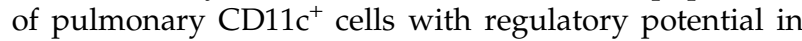
allergic mice. Eur J Immunol 2004; 34: 631-638.

156 Noon L, Cantab BC. Prophylactic inoculation against hay fever. Lancet 1911; 177: 1572-1574.

157 Abramson MJ, Puy RM, Weiner JM. Is allergen immunotherapy effective in asthma? A meta-analysis of randomized controlled trials. A J R Crit Care Med 1995; 151: 969-974.

158 Durham SR, Walker SM, Varga EM, et al. Long-term clinical efficacy of grass-pollen immunotherapy. $N$ Engl J Med 1999; 341: 468-475.

159 Bousquet J, Michel FB. Specific immunotherapy in asthma: is it effective? J Allergy Clin Immunol 1994; 94: 1-11.

160 Barnes PJ. Is immunotherapy for asthma worthwhile? N Engl J Med 1996; 334: 531-532. 
161 Frew AJ. 25. Immunotherapy of allergic disease. J Allergy Clin Immunol 2003; 111: 712-719.

162 Norman PS. Immunotherapy: 1999-2004. J Allergy Clin Immunol 2004; 113: 1013-1023.

163 Kay AB. Allergy and allergic diseases. Second of two parts. N Engl J Med 2001; 344: 109-113.

164 McHugh SM, Deighton J, Stewart AG, Lachman PJ, Ewan PW. Bee venom immunotherapy induces a shift in cytokine responses from a Th2 to a Th1 dominant pattern: comparison of rush and conventional therapy. Clin Exp Allergy 1995; 25: 828-838.

165 Rolland J, Ohehir R. Immunotherapy of allergy: anergy, deletion, and immune deviation. C O Immunol 1998; 10 : 640-645.

166 Secrist H, Chelen CJ, Wen Y, Marshall JD, Umetsu DT. Allergen immunotherapy decreases interleukin-4 production in $\mathrm{CD}^{+}{ }^{+}$T-cells from allergic individuals. J Exp Med 1993; 178: 2123-2130.

167 Akdis CA, Blesken T, Akdis M, Wuthrich B, Blaser K. Role of interleukin 10 in specific immunotherapy. J Clin Invest 1998; 102: 98-106.

168 Jutel M, Akdis M, Budak F, et al. IL-10 and TGF- $\beta$ cooperate in the regulatory $\mathrm{T}$ cell response to mucosal allergens in normal immunity and specific immunotherapy. Eur J Immunol 2003; 33: 1205-1214.

169 Nouri-Aria KT, Wachholz PA, Francis JN, et al. Grass pollen immunotherapy induces mucosal and peripheral IL-10 responses and blocking IgG activity. J Immunol 2004; 172: 3252-3259.

170 Gardner LM, Thien FC, Douglass JA, Rolland JM, O'Hehir RE. Induction of $\mathrm{T}$ "regulatory" cells by standardized house dust mite immunotherapy: an increase in CD4CD25 interleukin-10 T cells expressing peripheral tissue trafficking markers. Clin Exp Allergy 2004; 34: 1209-1219.

171 Van Oosterhout AJM, Vanesch B, Hofman G, et al. Allergen immunotherapy inhibits airway eosinophilia and hyperresponsiveness associated with decreased IL4 production by lymphocytes in a murine model of allergic asthma. Am J Respir Cell Mol Biol 1998; 19: 622-628.

172 Vissers JL, van Esch BC, Hofman GA, Kapsenberg ML, Weller FR, van Oosterhout AJ. Allergen immunotherapy induces a suppressive memory response mediated by IL10 in a mouse asthma model. J Allergy Clin Immunol 2004; 113: $1204-1210$.

173 Vissers JL, van Esch BC, Jeurink PV, Hofman GA, van Oosterhout AJ. Stimulation of allergen-loaded macrophages by TLR9-ligand potentiates IL-10-mediated suppression of allergic airway inflammation in mice. Respir Res 2004; 5: 21.

174 Akdis CA, Blaser K. Mechanisms of interleukin-10mediated immune suppression. Immunology 2001; 103 : 131-136.

175 van Neerven RJ, Wikborg T, Lund G, et al. Blocking antibodies induced by specific allergy vaccination prevent the activation of $\mathrm{CD}^{+} \mathrm{T}$ cells by inhibiting serum-IgE-facilitated allergen presentation. J Immunol 1999; 163: 2944-2952.

176 Sutterwala FS, Noel GJ, Salgame P, Mosser DM. Reversal of proinflammatory responses by ligating the macrophage FC $\gamma$ receptor type I. J Exp Med 1998; 188: 217-222.

177 Caramalho I, Lopes-Carvalho T, Ostler D, Zelenay S, Haury M, Demengeot J. Regulatory $\mathrm{T}$ cells selectively express Toll-like receptors and are activated by lipopolysaccharide. J Exp Med 2003; 197: 403-411.

178 Pasare C, Medzhitov R. Toll pathway-dependent blockade of $\mathrm{CD} 4+\mathrm{CD} 25+\mathrm{T}$ cell-mediated suppression by dendritic cells. Science 2003; 16: 16.

179 Eder W, Klimecki W, Yu L, et al. Toll-like receptor 2 as a major gene for asthma in children of European farmers. $J$ Allergy Clin Immunol 2004; 113: 482-488.

180 Levan TD, Von Essen S, Romberger DJ, et al. Polymorphisms in the CD14 gene are associated with pulmonary function in farmers. Am J Respir Crit Care Med 2004; Epub ahead of print.

181 Baldini M, Carla Lohman I, Halonen M, Erickson RP, Holt PG, Martinez FD. A polymorphism* in the 5' flanking region of the CD14 gene is associated with circulating soluble CD14 levels and with total serum immunoglobulin E. Am J Respir Cell Mol Biol 1999; 20: 976-983.

182 Howard TD, Postma DS, Koppelman GH, et al. Fine mapping of an IgE-controlling gene on chromosome 2q: Analysis of CTLA4 and CD28. J Allergy Clin Immunol 2002; 110: 743-751.

183 Lee SY, Lee YH, Shin C, et al. Association of asthma severity and bronchial hyperresponsiveness with a polymorphism in the cytotoxic T-lymphocyte antigen- 4 gene. Chest 2002; 122: 171-176.

184 Munthe-Kaas MC, Hakon Carlsen K, Helms PJ, et al. CTLA-4 polymorphisms in allergy and asthma and the TH1/TH2 paradigm, 2004; 114: 280-287.

185 van Oosterhout AJ, Deurloo DT, Groot PC. Cytotoxic T lymphocyte antigen 4 polymorphisms and allergic asthma. Clin Exp Allergy 2004; 34: 4-8.

186 Godfrey WR, Ge YG, Spoden DJ, et al. In vitro expanded human $\mathrm{CD}^{+} \mathrm{CD} 25^{+} \mathrm{T}$ regulatory cells can markedly inhibit allogeneic dendritic cell stimulated MLR cultures. Blood 2004; 104: 453-461.

187 Bluestone JA, Tang Q. Therapeutic vaccination using CD4+CD25+ antigen-specific regulatory T cells. Proc Natl Acad Sci USA 2004; 101: Suppl. 2, 14622-14626.

188 Hoffmann P, Eder R, Kunz-Schughart LA, Andreesen R, Edinger M. Large scale in vitro expansion of polyclonal human $\mathrm{CD}^{+} \mathrm{CD} 25$ high regulatory T cells. Blood 2004; 104: 895-903.

189 Roncador G, Brown PJ, Maestre L, et al. Analysis of FOXP3 protein expression in human CD4+ CD25+ regulatory $\mathrm{T}$ cells at the single-cell level. Eur J Immunol 2005; 25: 1681-1691. 